\title{
COMPENSATION TO VICTIMS OF CRIME
}

\begin{abstract}
GEORGE J. BRYAN, Q.C.*
That a victim of crime should be without redress for the injury he suffers is an anomaly in the administration of justice. Mr. Bryan considers the legislation presently in force, points out the basic problems, and discusses the approaches employed in other jurisdictions. He concludes that there should be less emphasis on punishment for the crime against the state and more emphasis on compensation to the victim of the crime.
\end{abstract}

Normally in preparing a paper on a legal subject the writer consults the legal digests, the textbooks on the subject, and then reads all the cases he can find before commencing to write. There are, however, no cases on the subject of compensation to the victims of crime and only three or four very recent statutes. One is forced to obtain his material from articles, learned treatises, white papers and the reports of study groups. As the British White Paper points out:

Until the coming into force on 1st January, 1964 of the New Zealand Criminal Injuries Compensation Act no other country in the world had a scheme of compensation of the type that has been discussed in this country. ${ }^{1}$

For this reason the British government considered it best to set up a flexible scheme that could be altered in the light of experience.

All this writer can hope to do therefore is to consider the legislation presently in effect, point out the basic problems and the different approaches used in different jurisdictions. While it is too early to draw any definite conclusions as to the effect of this legislation, perhaps it is not too soon to speculate with regard to results that might be obtained as the schemes are developed.

To consider properly the question of compensation to the victims of crime it is necessary to review at least briefly the attitude that the law has taken over the years toward the criminal and his victim. The principle that a wrongdoer should pay compensation to his victim appears in many ancient legal codes as far back as the code of Hammurabi. In Western Europe during the middle ages as the tribes settled down to a less warlike life, vengeful retaliation through the blood feud and the vendetta gave way to compensation which provided a combination of punishment and damages. The laws of the early Germanic peoples, the Franks and the Anglo-Saxons required that compensation be paid by a wrongdoer to the victim or his family and the amount so paid be based on the extent of the injury and the age, sex, prestige or rank of the victim. The subjective aspects of the crime were not considered.

Gradually, during the middle ages, the power of the kings and the barons increased and the enforcement of law and order fell more and more into their hands. For the enforcing of the King's Peace a larger and larger portion of the compensation paid by the wrongdoer was exacted by the rulers. Gradually the injured person's right to compensation in this way became less and the amount paid by the wrongdoer became a fine payable to the state. The rights of the victim separated

- B.A., LL.B. (Alta.), of the Edmonton firm of Bryan, Foote, Andrekson, Wilson, Ostry, Bryan \& Boyer.

1 Home Department, Compensation for Victims of Crimes of Violence Cmd. 2323 (1964), 4. 
from the penal law and became a special field of civil law-the tort. This theory that a criminal act was an offence exclusively against the state severed the connection between compensation and punishment.

At the present time in the majority of jurisdictions, criminal and civil law is administered by separate courts or at least in separate hearings. Any claim for compensation is treated as a civil matter only, even though the injury was caused by a criminal act. It is felt by many that the claim by a victim for compensation cannot properly be dealt with when the question of the guilt or innocence of the alleged wrongdoer is being decided, since the judge or jury might be influenced by the seriousness of the injury inflicted on the victim, in deciding the question of the guilt or innocence of the accused, or on the other hand the verdict might influence the amount of compensation awarded.

Many countries endeavour to keep associated the crime and the compensation to the victim by the so-called "adhesive procedure." In Germany, for example, the victim's claim may be heard at the same time as the criminal case although it is still.treated as a separate decision. In France "l'action civil" is a somewhat similar procedure. Generally such procedure is an alternative and the civil character of the victim's claim is emphasized although it is allowed to be brought forward during the criminal proceedings.

However, in most jurisdictions, as in our own, the victims can only look to the civil courts to obtain compensation for their injuries with little hope of collecting even if their suit is successful. The criminal is rarely a man of substance and even though the damage arose through his criminal act he still has the protection of any exemption acts available to ordinary debtors.

The public is becoming more and more concerned with regard to the hardship inflicted on the victim of crime insofar as his inability to obtain compensation or redress for his injuries is concerned. Public opinion has forced legislation to assist in the rehabilitation of the criminal and governments are spending millions to this end. We provide free medical care and hospitalization to the victims of cancer, tuberculosis and many other diseases, and we provide pensions for the aged; yet in none of these cases can the state be said to be the cause of the situation. Yet in the case of injury caused to a victim of crime the state which took away from the victim the means of protecting himself against such injury has failed to provide an alternative protection for him. Prins, the great Belgian criminologist, in 1895 stated:

The guilty man lodged, fed, clothed, warmed, lighted and entertained at the expense of the state in a model cell issued from it with a sum of money lawfully earned has paid his debt to society, he can set his victim at defiance, but the victim has his consolation he can think that by taxes he pays to the Treasury he has contributed to the paternal care which has guarded the criminal during his stay in prison. ${ }^{2}$

If a philosophic base is needed for compensating victims of crime, the words of the Bishop of Chester should provide it:

If society by its indifference to those things which inculcate proper behavior continues to make its contribution to the breeding of criminals, it must accept

a large measure of responsibility for the consequences of criminal acts. ${ }^{3}$

2 The Paris Prison Congress, 1895, Summary Report (London).

3 As cited by Professor J. L. T. Edwards, Compensation to Victims of Crimes of Personal Violence, 1966 Federal Probation. 
The British Government in its White Paper No. 2323 stated, that although it would not accept responsibility for the situation:

The government accepts the principle that the victims of crimes of violence should be eligible for some compensation for personal injury at the public expense. . . Compensation is to be paid ex gratia. The government does not accept that the state is liable for injuries caused to people by the acts of others. ${ }^{4}$

If we agree that the victim should be compensated, then such compensation must come either from the wrongdoer or the state.

In cases in which the state has endeavoured to keep compensation closely associated with the criminal law the greatest effort has been made to force the wrongdoer to pay the compensation. Theoretically the most complete system is the Cuban system. In this case the criminal court, on finding a person guilty, has the widest powers to fix the amount of compensation to be paid the victim. This sum is paid to the victim out of a fund set up by the government and repayment to the fund on such terms as the judge may deem just becomes part of the criminal's sentence. If he does not have the money to pay he can be confined in a penal institution until he has served his sentence and has earned enough at the standard wages that are paid to him to compensate the fund.

This procedure shows a concern for the victim and perhaps is a recognition by the state that it has failed to protect him. Modern criminology veers away from retribution but it does not object to forced restitution. Perhaps punishment, as in the Cuban procedure, should lean towards giving the criminal a chance to work his way back to society by making the criminal's sentence benefit the victim.

In English speaking countries a number of acts have been passed to assist the victims of crime by payments from government funds. The first of these acts was the New Zealand Criminal Injuries Compensation Act $^{5}$ passed in 1963, followed by the British Plan to provide Compensation for Victims of Crimes of Violence in $1964,{ }^{\circ}$ the California Act in $1966^{7}$ and the Saskatchewan Criminal Injuries Compensation Act in 1967.8 There have been a number of other acts proposed in other provinces and states.

It might be well to outline with particular attention to the following matters the provisions of the New Zealand, British and Saskatchewan Plans, with some lesser references to the California Act:

(a) The injuries for which compensation may be obtained.

(b) The Compensation Boards and their procedures.

(c) The powers of the Boards and appeals therefrom.

(d) The limitation on amount of payments.

(e) The exclusions from the Acts.

(f) General.

New Zealand Act

(a) The Act applies to any person who is injured or killed by any act or omission of any other person within the offences specified in the schedule set out in the Act. Injury means actual bodily harm including pregnancy, and mental or nervous shock. The

4 Supra, n. 1, at 4.

5 S.N.Z. 1963, c. 134.

boc. cit. supra, n. 1. See also an earlier circular issued by the British Home Office, Cma. 1406 (1961).

7 California Penal Code No. 12600—03, 1965 Regular Session c. 1395.

8 S.S. 1967, c. 84 . 
schedule includes most offences from which injury or shock might be expected to arise.

(b) The Board consists of three men, one of whom must be a lawyer of at least seven years standing. The hearings must be held in public except when the offender has not been convicted, it is a sexual case or it is not in the interest of public morality to have it in public.

(c) The Board is constituted a Commission of Inquiry with all powers given such a body. The tribunal may prohibit publication of the name of the victim or of any of the evidence taken at the hearing. It may make such order regarding costs as it deems advisable. The board may consider the conduct of the victim and shall deduct from compensation awarded amounts that the victim recovers from the wrongdoer or recovers under various specified acts by reason of the injury. There is no appeal from the board.

(d) The board may award compensation for expenses incurred by the victim, loss of wages, loss to dependents and pain and suffering. The tribunal shall award such amount as it thinks fit either as a lump sum or in periodic payments, provided such amount does not exceed $£ 500$ for pain and suffering and $£ 1000$ for expenses plus, in the case of loss of ability to work, an award of $£ 10$ 5s. per week plus $£ 1$ for a wife and 10 shillings per child, such payments not to be made for more than six years.

(e) Compensation cannot be awarded for pain and suffering if it is caused to a relative of the offender or anyone living with the offender as wife, husband or a member of the offender's family.

(f) Monies are paid out of the consolidated fund and are not assignable or subject to attachment. Where a person has been convicted the Secretary of Justice may make an order directing the offender to repay the money advanced. Any recovery made by the victim must be used to reimburse the fund.

\section{British Plan}

(a) The plan applies to any person who is injured by reason of any criminal act. Compensation is payable whether or not the offender is convicted. A second part of the plan extends its benefits to persons injured in trying to arrest an offender, in trying to prevent the commission of a criminal offence, or in endeavouring to assist a peace officer.

(b) The board consists of five members all with legal experience. The hearings are not public and are as informal as possible.

(c) The board may call, examine and cross-examine witnesses and consider provocation by the victim. The board may require the recipient of any award to sue the offender and if successful to repay the board. Decisions are not subject to appeal or ministerial review. The board has no power of recovery from the wrongdoer.

(d) The board may award such amount as it deems just on the basis of common law damages except that in the case of loss of earnings it shall not exceed twice the average of industrial earnings 
at the time of the injury, shall not include exemplary or punitive damage or loss of expectation of happiness. Awards must be paid in a lump sum except in extraordinary cases. A rich person cannot be awarded more than $£ 36$ per week. Money for payments is made available by the government by a "grant in aid."

(e) Offences committed against members of the offender's family do not come within the plan, nor do motoring offences except where a car is used as a deadly weapon.

(f) The board in its first report suggested that perhaps there should be a schedule of crimes to which the plan applied, with the board having power to make awards in other cases if justice required it. It also pointed out the problems that arise when the wrongdoer is found not guilty by reason of insanity or where he is too young to commit a crime.

\section{Saskatchewan Act}

(a) The act applies to every person injured or killed as a result of an act or omission of a wrongdoer while committing any of the criminal offences specified in the act or suffered as a result of arresting or attempting to arrest a person committing a criminal offence or suffered in assisting a peace officer in the performance of his duty. Injury means actual bodily harm and includes pregnancy and mental or nervous shock. Even if the wrongdoer is legally incapable of forming a criminal intent he is deemed for the purposes of this act to have intended to commit the act.

(b) The Crimes Compensation Board is composed of three persons and no member need have legal training. The hearings must be public except where the board considers that the hearings should be in camera. Hearings in the following cases must be private-

(1) where the wrongdoer has not been charged or was acquitted,

(2) in sexual cases where the interests of the victim would require them to be heard in camera,

(3) where a public hearing would not be in the public interest.

(c) The Board is given the powers granted a commissioner under The Public Inquiries Act. The Board shall consider the behavior of the victim and the financial need of the person who was injured or his dependents. No provision is made for an appeal from the decisions of the Board. If the victim sues the wrongdoer, the fund is to be reimbursed out of any amount so recovered. The Board may on the application of the Attorney General require the wrongdoer to appear before it to show cause why he should not be required to repay all or any part of the award made to the victim. The Board may make an order requiring payment, which order may be filed in the Court of Queen's Bench and enforced as a judgment of that court, but in such case it is subject to appeal.

(d) The Board may award compensation for expenses actually and reasonably incurred by the victim or his dependents, pecuniary loss resulting from loss of ability to work, loss to dependents through death of the victim, other pecuniary loss and pain and 
suffering. Payment may be ordered in a lump sum or in periodic payments. The Board must deduct from the amount awarded any amount recovered under any Dominion or Provincial Act by reason of the injury or any amount recovered from the wrongdoer. Payments made by way of superannuation are not be so deducted.

(e) The act excludes from its provisions injuries resulting from offences committed against members of the wrongdoer's own family living with him, and also excludes injuries suffered by reason of acts committed in the commission of criminal offences not enumerated in the schedule to the act.

(f) The compensation payable under the act comes from the consolidated fund of the Province. The Lieutenant-Governor in Council may fix the maximum amount of compensation that may be awarded and may make regulations respecting the carrying out of the provisions of the Act. Thus the Government retains a tight control on the amount that can be paid out under the act.

It might be well now to draw attention to some of the differences between the various acts. It must be pointed out that, in drafting their schemes to compensate the victims of crime, New Zealand, Britain and Saskatchewan had virtually no previous experience on which to draw when considering the form the legislation should take. Information is gradually being accumulated in New Zealand and Britain that will assist in the drafting of future acts. It might also be well to list some of the basic problems that had to be considered and the decisions reached.

The first basic problem that confronted the government was whether or not the scheme should be limited to compensation for personal injury. If damage by reason of fraud was included the claims could become very substantial and if riot was included they could be astronomical. It was felt that property losses could be insured against and therefore should not be covered by the scheme. The limiting of claims to personal injury is followed in all schemes now in operation. While from a financial standpoint it may be necessary to draw this distinction, philosophically it is hard to draw any such distinction. Personal injuries can also be insured against and loss of property through arson, for example, can be just as disastrous to the individual as personal injury. Perhaps in the future some middle ground may be taken with compensation paid for property loss in a limited number of cases where the victim has not contributed to the loss by his own neglect.

The question next to be considered was whether injury arising from all criminal acts should be covered. Under the British Plan all crimes are included, while New Zealand and Saskatchewan have schedules enumerating certain crimes that are covered by the Act. In checking the different schedules it is difficult to understand the reasoning behind the inclusion or rejection of certain offences. Perhaps the best solution is that recommended by the British Board, namely, that there should be a schedule with the Board having power to award compensation in extenuating cases not covered by the schedule.

The British Plan excludes injuries caused to the members of the wrongdoer's family, the New Zealand Act limits this exclusion to compensation for pain and suffering, while the Saskatchewan Act follows 
the British procedure. The British Plan also excludes injuries arising from the operation of a motor vehicle unless it is used as a weapon to commit a crime. The British White Paper also directs the Board to scrutinize with great care all applications in respect of sexual offfences.

Another basic problem that had to be considered is the question of the limitation placed on the amount that may be paid to a victim. Under the British Plan there is no limitation and the basis for payment is the amount that would be paid at common law. In New Zealand strict limits are placed on the amounts that may be paid for various types of injury. The Saskatchewan Act while it places no restrictions on the Board does provide that the Lieutenant-Governor in Council may make regulations for the carrying out of the provisions of the Act which could include the amounts to be paid as compensation. The California Act introduces a different concept, namely, that the right to compensation should be tied to need, and strict income criteria are applied-the income of the whole family must be less than $\$ 239.00$ per month before compensation is paid. Most jurisdictions are placing their schemes on the basis of true compensation rather than on the basis of another handout.

Under the British procedure a difficulty arose in the case of a person injured by the act of a child below the age of criminal responsibility or by a person who subsequently was found not guilty by reason of insanity. Had the victim been injured by a criminal act? This difficulty was removed by a statement by the Home Secretary in the House of Commons that injuries would not be outside of the compensation scheme solely for this reason. ${ }^{9}$ In New Zealand and Saskatchewan this has been overcome by a provision stating that a person legally incapable of forming a criminal intent shall be deemed to have intended the act or omission for the purpose of the Act.

There is one other difference that we should consider. The British procedure includes injuries suffered by persons in arresting a wrongdoer, preventing a crime or assisting a police officer. The Saskatchewan Act covers injuries incurred in arresting a wrongdoer and assisting a police officer but not ones incurred in preventing a crime. New Zealand Act contains no such provisions.

As pointed out in the British White Paper in March of 1964:

There being virtually no previous experience anywhere in the world to draw upon, the Government readily accept that there is scope for argument both on the principles and on the details of any compensation scheme and do not claim that the proposals proposed in this White Paper are incapable of improvement in the light of experience. ${ }^{10}$

Since the British scheme was inaugurated, experience has been gained principally in Britain and New Zealand, and a great deal of statistical information has been compiled which will give direction on many of the problems that concern those governmental bodies considering such a scheme.

There are three other problems that must be considered, namely:

(a) The cost of the program. During the first year of the operation of the British and New Zealand schemes the cost of such operation was less than anticipated but it may be that this is due to the fact that the public is unfamiliar with the operation of the act and as a result few 
claims have been made. The cost of the program is of course directly affected by the limitations placed on the types of cases covered by the plan and the limitations placed on the amount of compensation to be paid.

With regard to the limitations placed on the types of cases, as is shown earlier, most plans are limited to personal injuries suffered as a result of crimes of violence; some plans have a limited list of offences and some exclude sexual offences and offences committed against members of the wrongdoer's own family. The reasons given for the differences in the plans range from the difficulty of ascertaining the validity of the claim, the fear that the wrongdoer may indirectly benefit from the compensation, the fear of fraud or collusion to the fear of making the system too costly or too difficult to operate.

The limitation placed on the amount of the compensation ranges all the way from the amounts paid at common law to schedules fixing very specific amounts to be paid for each type of injury.

These limitations, while they control the amount to be paid by the government, do bring to the forefront the fact that a decision must be made as to whether any scheme to be brought into effect is to be a true compensation scheme protecting all victims of crimes of violence or whether it is to be merely another welfare scheme.

(b) Will compensation affect the crime rate. This question is one that has been argued back and forth many times. One side argues that the assurance of compensation will mean that more persons will try to prevent crime and will come to the assistance of peace officers. The British government felt that this would be the case and Sir Walker Carter a member of their board stated the police were pleased with the increasing response by the public to the calls for assistance by police officers and he attributed this to the operation of the compensation scheme. ${ }^{11}$ On the other side there is the argument that there will be more crimes of violence if the wrongdoers know that their victims will be compensated. It is however hard to believe that a criminal bent on a crime of violence will consider whether or not his intended victim will be compensated. It is likely too early to assess the effect of this legislation in this regard.

(c) Can the scheme be used to correlate punishment and compensation. Many criminologists believe that the concept of reparation to the victim should be added to the concepts of deterrence by punishment and reform by training. The Council of the Law Society of England felt that the most powerful deterrents to crimes committed for the acquisition of gain are certainty of detection and reasonable certainty of the loss of such gains. To this might be added the certainty of having to pay compensation to the victim.

The present state of our legal thinking would not, I am sure, permit the return of our penal system to anything similar to that in vogue in the days of bot and wergild; but perhaps we can evolve a system where penalties are set by the criminal courts, rehabilitation is attempted under our penal system, the victim is compensated by the state, and the state recovers from the wrongdoer.

11 Sir Walker Carter. The Work of the Criminal Injuries Compensation Board (1966). 34 Medico-Legal Journal 48. 
A sentence of imprisonment could in some cases openly provide for its reduction if compensation were paid the victim or compensation could be made a condition of the wrongdoer's parole. In other cases the criminal after serving his sentence could have given against him a judgment for the repayment of the money paid by the government to the victim, which judgment would not be subject to the exemptions that protect a debtor in the case of ordinary civil litigation.

While this procedure would have little effect on the worthless criminal, yet in many cases it would be very salutory and would leave the criminal with the feeling that he had paid his debt to society and to his victim. This need not be a piling of one sentence on another but merely a needed readjustment of emphasis-less emphasis on punishment for the crime against the state and more emphasis on the compensation of the victim. 